\title{
Competing in the Global Solar Photovoltaic Industry: The Case of Taiwan
}

\author{
Yu-Shan Su \\ National Taiwan Normal University, Taipei, Taiwan \\ Correspondence should be addressed to Yu-Shan Su; yssu@ntnu.edu.tw
}

Received 23 November 2012; Revised 26 January 2013; Accepted 4 February 2013

Academic Editor: Ching-Song Jwo

Copyright (C) 2013 Yu-Shan Su. This is an open access article distributed under the Creative Commons Attribution License, which permits unrestricted use, distribution, and reproduction in any medium, provided the original work is properly cited.

The top five solar cell supply countries in the world in sequential order are China, Taiwan, the United States of America, Japan, and Germany. The capacity of Taiwanese solar cell production is ranked top two in the globe. The competitive advantage of the Taiwanese electronics firms has facilitated the rapid developments to its solar photovoltaic industry. The Taiwanese solar photovoltaic industry possesses a large size and a complete value chain of upstream, midstream, and downstream sectors. In this study, I analyzed the trends and developments of the solar photovoltaic industry in Taiwan and in the globe. And I also investigated the positioning and competitive advantage of Taiwanese firms in the value chain of the global solar photovoltaic industry. I found that Taiwanese firms continue to have an important and indispensable role in the global solar photovoltaic industry by either differentiation or cost advantage.

\section{Introduction}

The shortage of global fossil fuels has led to many countries prioritizing the developments of the long-lasting solar photovoltaic (PV) industry. The top five solar cell suppliers in sequential order are China, Taiwan, the United States of America (USA), Japan, and Germany in the world $[1,2]$. The capacity of Taiwanese solar cell production is ranked top two in the globe [3]. The competitive advantages of Taiwanese electronics firms have facilitated the rapid developments to the solar photovoltaic industry. In this study, the positioning of the Taiwanese firms in the value chain of the global solar photovoltaic industry is analyzed. And the opportunities and advantages of Taiwanese solar photovoltaic firms are discussed.

Based on the competitive advantage of the electronics industry, Taiwanese firms entered to the solar photovoltaic industry rapidly [3]. The Taiwanese solar photovoltaic industry has been developing for the 25 years and built up a complete industrial value chain. In 2011, the revenue of the Taiwanese solar photovoltaic industry was US $\$ 5.6$ billion: (1) the revenue of the midstream sector of the silicon wafer and thin-film photovoltaic cells was approximately US $\$ 3.8$ billion, which accounts for $70 \%$ of all industry revenue in Taiwan; (2) the revenue of the upstream sector of the solar silicon materials was approximately US $\$ 1.5$ billion; (3) the revenue of the downstream sector of the solar photovoltaic system was approximately US\$283 million (see Figure 1) [1]. Currently, there are approximately 131 companies in Taiwan. Furthermore, a number of Taiwanese companies, such as Motech Industries Incorporation, Gintech Energy Company, and Neo Solar Power Corporation, are on the top ten companies list in the world.

The top five countries with the highest demand for global photovoltaic devices were Italy, Germany, the United States, China, and Japan in 2011 [1,2]. Because European governments have reduced their subsidies, the demand of the European market for photovoltaic devices is expected to decline from the $80 \%$ for 2010 to $41 \%$ by 2020 [4]. Global demands for solar cells are expected to increase significantly. The emerging markets will be in Asia, Northern America, and Latin America in the future. Taiwanese firms have become the leading global suppliers of the solar photovoltaic products for the three reasons: (1) stable product quality, (2) mature technologies, and (3) reasonable pricing. In this study, I analyzed the positioning of the Taiwanese firms in 


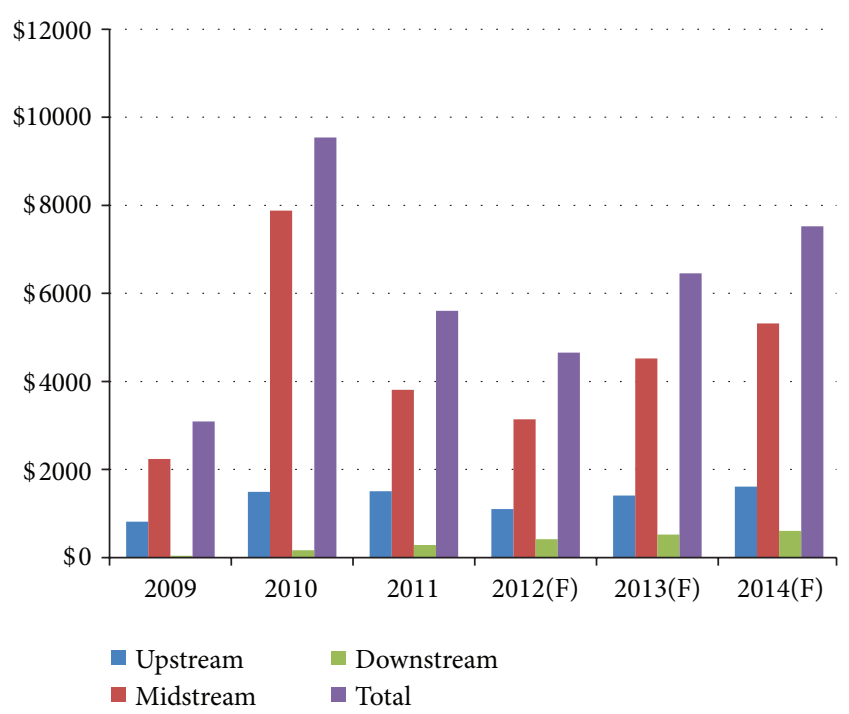

FIGURE 1: Revenue of Taiwanese solar photovoltaic industry. Upstream: silicon material; Midstream: solar cell (wafer-based; thinfilm) and solar cell module; Downstream: solar photovoltaic system. Source: adapted from PIDA (2012) [1].

the value chain of the global solar photovoltaic industry and further investigated the opportunities and advantages of the Taiwanese solar photovoltaic firms.

\section{Analysis of Global Solar Photovoltaic Industry}

2.1. Scope of Solar Photovoltaic Industry. The solar industries are categorized as three types according to their products: (1) the solar photovoltaic industry, (2) the solar thermal energy industry, and (3) the solar source industry. In this study, we focused only on the solar photovoltaic industry. Companies that comprise the value chain of the solar photovoltaic industry are categorized as (1) upstream: silicon materials and silicon wafer, (2) midstream: solar cells and solar photovoltaic modules, and (3) downstream: solar photovoltaic systems [5].

2.2. Value Chain Analysis of Global Solar Photovoltaic Industry. Regarding the global solar photovoltaic industry (see Figures 2 and 3), the upstream industry achieves the highest profit because the market is oligopolistic $[1,11,12]$. The midstream industry achieves the lowest profits. And the downstream industry, including device installation and warranty maintenance, achieves the second highest profits [13]. The revenue of the solar photovoltaic industry is globally predicted to reach US $\$ 150$ billion in 2014 [1].

The top five solar cell supply countries in the world, in sequential order, are as follows: China, Taiwan, the United States, Japan, and Germany (see Table 1) [6]. The mature technologies of the USA and Japanese companies can serve as the most important technology sources in both the first and new generation solar photovoltaic industries of Taiwan and China [14]. Currently, the technology latecomers Taiwan

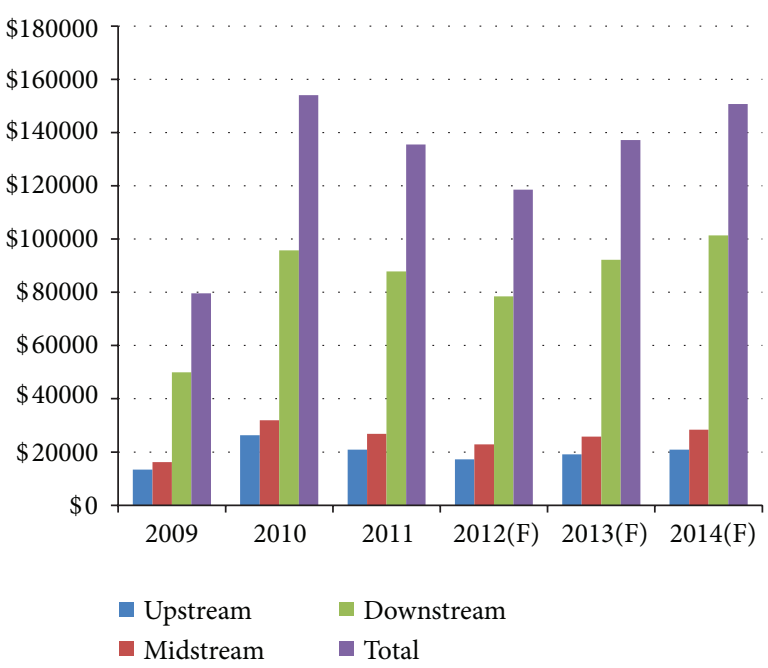

FIGURE 2: Revenue of global solar photovoltaic industry. Upstream: silicon material; Midstream: solar cell (wafer-based); Downstream: solar cell module and solar photovoltaic system. Source: adapted from PIDA (2012) [1].

have built up their innovation capabilities in certain solar photovoltaic sectors.

The Taiwanese solar cell industry possesses research and development (R\&D) abilities and exhibit significant international competitiveness. In 2011, three of the top ten solar cell companies in the world were Taiwanese companies, that is, Motech Industries Incorporation, Gintech Energy Company, and Neo Solar Power Company. The production capacity of the firm Motech, Gintech, and Neo Solar Power was 4\%, 3\%, and $3 \%$, respectively [6].

(1) Upstream Sector. In 2011, the production capacity of the upstream silicon wafer companies in China and Taiwan was $58 \%$ and $9 \%$ of the global total, respectively [1]. The largest polysilicon companies in the world are Golden Concord Holdings Limited and LDK Solar Company in China, followed by Wacker Chemie AG in Germany and Hemlock Semiconductor Group in the United States. Regarding the top ten silicon wafer companies in the world, five companies are located in China and two companies are in Taiwan, that is, Green Energy Technology and Sino American Silicon Products Incorporation.

(2) Midstream Sector. The global capacity of the module production for the top ten solar cell companies is approximately 50\% [17]. The technology of first-generation devices has diffused to the rising industrial powers of Taiwan and China, though the early solar cell producers were found in Europe, the United States, and Japan [18]. In 2011, the capacity of the solar cells production from Chinese and Taiwanese firms was $61 \%$ and $15 \%$ of the global total, respectively [1]. The Taiwanese technologies of cell conversion efficiency are superior to those employed by Chinese firms, but $17 \%$ export tax rebate facilitates competitive prices in China [19].

Top ten suppliers of the solar photovoltaic module are (i) North America: First Solar Incorporation in the United 
TABLE 1: Top 10 global solar photovoltaic suppliers.

\begin{tabular}{lccc}
\hline & 2009 & 2010 & 2011 \\
\hline 1 & First Solar (USA) & Suntech (China) & First Solar (USA) \\
2 & Suntech (China) & JA solar (China) & JA solar (China) \\
3 & Sharp (Japan) & First Solar (USA) & Suntech (China) \\
4 & Q-Cells (Germany) & Trina (China) & Yingli (China) \\
5 & Yingli (China) & Q-Cells (Germany) & Trina Solar (China) \\
6 & JA solar (China) & Yingli (China) & Motech (Taiwan) \\
7 & Kyocera (Japan) & Motech (Taiwan) & Gintech (Taiwan) \\
8 & Trina (Chian) & Sharp (Japan) & NSP (Taiwan) \\
9 & SunPower (USA) & CSI (China) \\
10 & Gintech (Taiwan) & Kintech (Taiwan) & SunPower (USA) \\
\hline
\end{tabular}

Source: Solarbuzz (2012) [6].

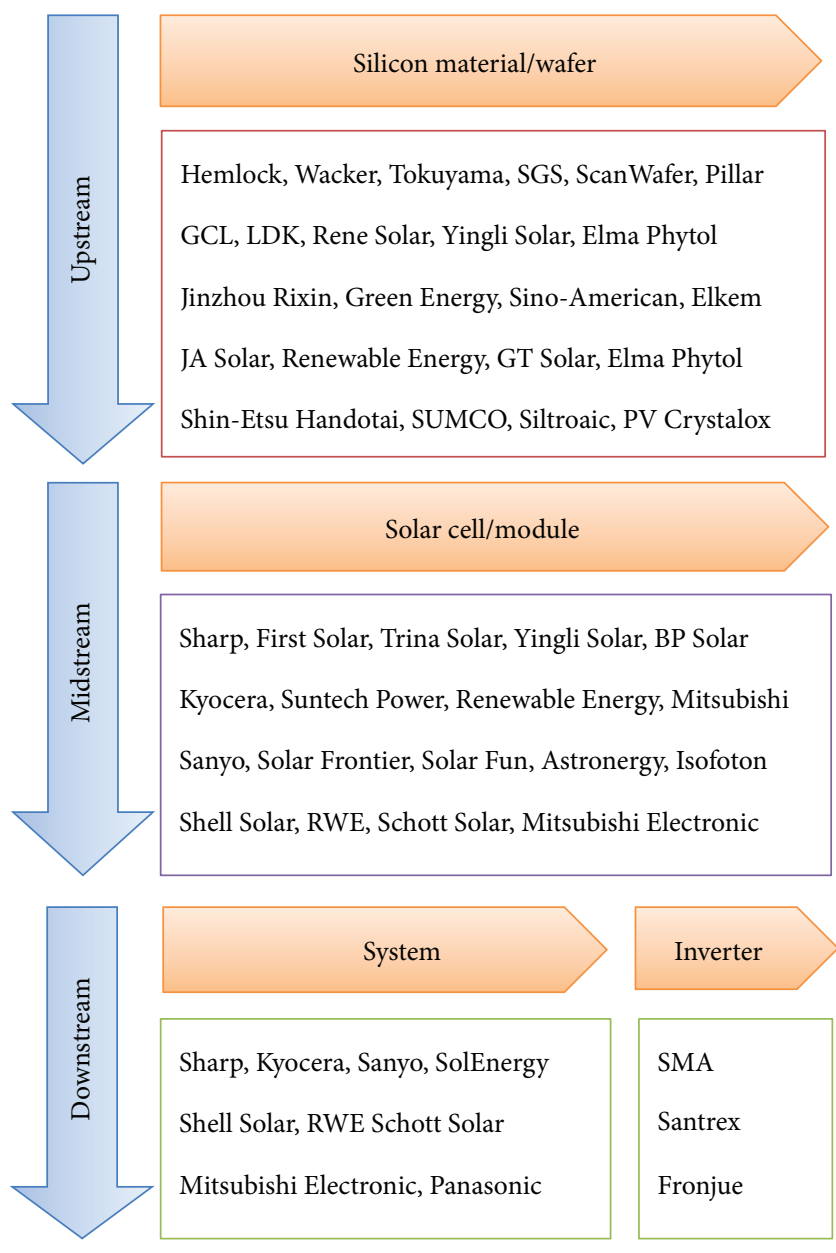

FIGURE 3: Value chain of global solar photovoltaic industry. Source: PHOTON International (2012) [11] and ITRI (2012) [12].

States and Canadian Solar Incorporation in Canada; (ii) Asia: Trina Solar, Yingli Green Energy, Suntech Power, Solarfun in China; Motech Industries Incorporation, Gintech Energy Company, and Neo Solar Power Corporation in Taiwan; Sharp Corporation and Solar Frontier Company in Japan. Thin-film photovoltaic cells are led by Solibro Corporation in Germany and Solar Frontier Company in Japan. Triple amorphous silicon cells are led by Sharp Corporation in Japan and Astronergy Company in China.

(3) Downstream Sector. The downstream sector is a market of perfect competition because of the maturity of manufacturing technologies and low barriers to entry. Japanese Sharp Corporation, Sanyo Electronic Company, and Mitsubishi Electronic Company have the largest scale in solar photovoltaic system integration. German SMA Solar Company is the leading supplier of the solar photovoltaic converters in the world. Taiwanese Delta Electronics and Motech Industries Incorporation have the strong advantages in this sector.

Currently, companies that employ vertical integration and cross-border cooperation have the most competitive advantages. For one example, German Q.CWLLS Company and Chinese LDK Solar Company have entered a joint venture to establish downstream system companies. For the other example, Taiwanese E-Ton Solar Company has invested in Taiwanese Gloria Solar Company and formed a joint venture with U.S. Spire Corporation to establish a new company called Gloria Spire Solar for producing solar photovoltaic systems.

2.3. Global Capacity Analysis. The top five countries in the world for solar cell production were as follows: China, Taiwan, Japan, the United States, and Germany in 2011 (see Figure 4) [1]. Patents on first generation silicon cells have now largely expired and open to Taiwanese and Chinese companies that are crowding into this space [18]. Taiwanese and Chinese firms, as fast followers, are now establishing themselves as major players in the industry as producers, investors, and exporters.

The capacity of the solar cell production of China and Taiwan accounts for $62 \%$ of the global total in 2010 (see Figure 4) [1]. The Taiwanese production capacity (15\%) is ranked second worldwide, behind China, which has the highest capacity of the solar cell production (61\%) [1]. The difference of the production capacity between Taiwan and China increased from $34 \%$ in 2010 to $46 \%$ in 2011 . Thus, Taiwanese firms should continuously increase technological $\mathrm{R} \& \mathrm{D}$ to expand its global market share. 


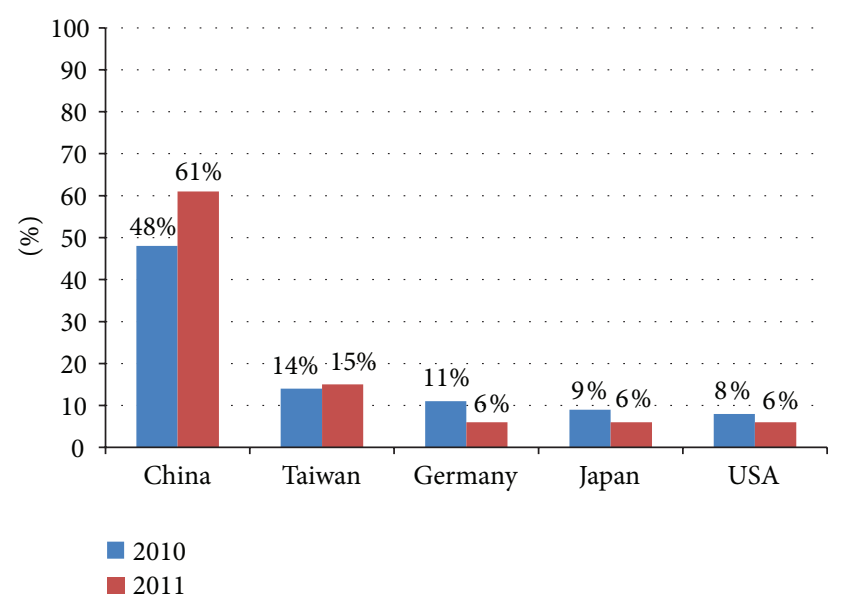

FIGURE 4: 2010-2011 global solar photovoltaic production capacity. Source: PIDA (2012) [1].

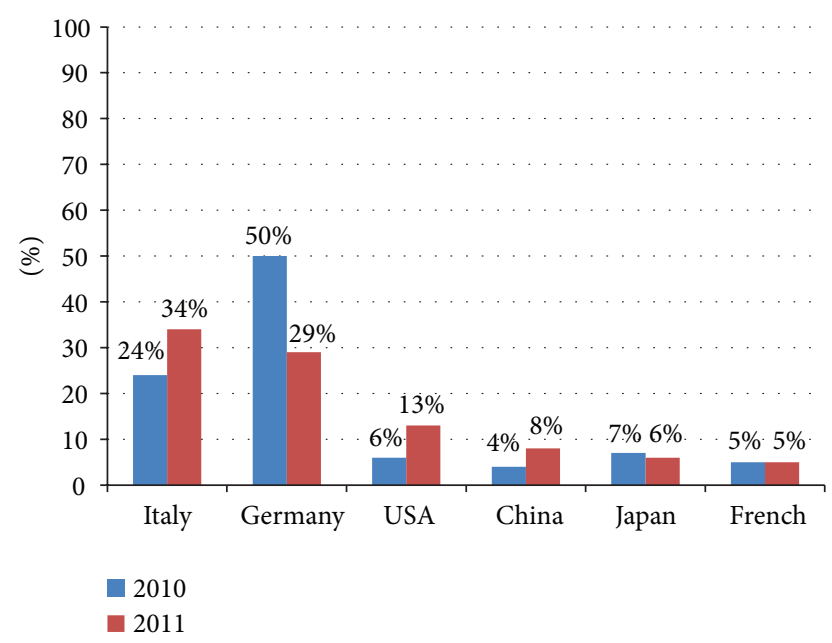

FIgURE 5: 2010-2011 global solar photovoltaic device market. Source: PIDA (2012) [1].

2.4. Global Market Analysis. The five countries with the highest demand for solar photovoltaic devices in 2011 were Italy, Germany, the United States, China, and Japan (see Figure 5) [1,2]. These demands accounted for $80 \%$ of the total market demand. Sustained policy support in countries such as Germany, Italy, United States, Japan, and China attributed to the impetus behind the recent growth of solar technologies [20]. The global installed capacity for PV had reached around 40 GW by December 2010 of which $85 \%$ were grid connected and the remaining were $15 \%$ off-grid [20]. The market of the global solar energy installations reached $18.2 \mathrm{GW}$ in 2010; compared to that of 2009, a positive growth of $139 \%$ was observed [6]. The global solar cell production reached $29.5 \mathrm{GW}$ in 2011, of which $7 \mathrm{GW}$ to $8 \mathrm{GW}$ was produced by Taiwan [6]. Thus, more than $24 \%$ of the global productions are contributed by the Taiwanese firms.

Furthermore, the reduction of the Italian and German government subsidies for the solar photovoltaic installations, and the European debit crisis, resulted in a $20 \%$ decline in

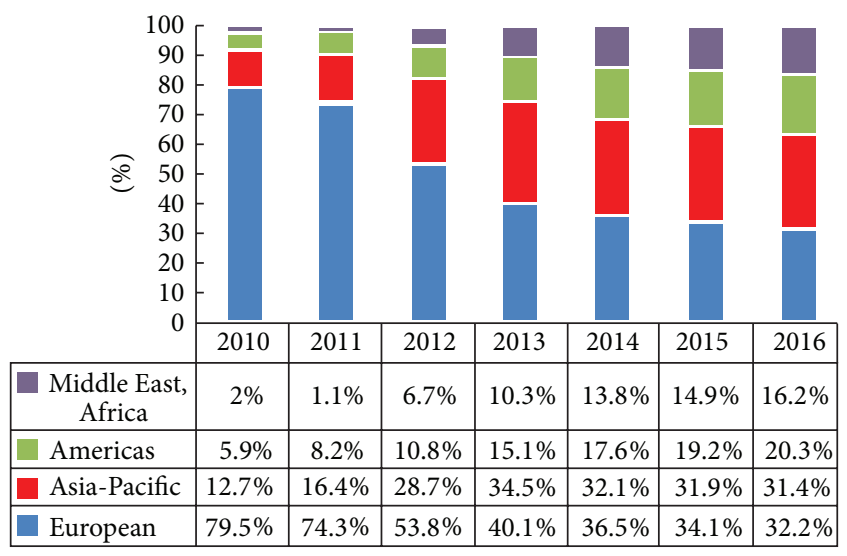

FIGURE 6: 2010-2016 global solar photovoltaic market (by geographic area). Source: ITRI (2012) [12].

solar photovoltaic demands in 2011 compared to that in 2010 [6]. Thus, demand from the European market is predicted to be between 45\% and 54\% in 2015 [6]. The North American and Asian markets are set to become the next high-demand markets. Additionally, Middle East and African regions will be the emerging markets in the future (see Figure 6) [12]. If existing market supports are continued and additional market support mechanisms are provided, a dramatic growth of solar PV would be possible, which will lead to worldwide PV-installed capacity rising from around $40 \mathrm{GW}$ in 2010 to $1845 \mathrm{GW}$ by 2030 [20]. And the capacity would reach over $1000 \mathrm{GW}$ in 2030 even with a lower level of political commitment [20].

\section{Emergence of the Taiwanese Solar Photovoltaic Firms}

3.1. Strength of the Taiwanese Electronic Industry. There are the successful semiconductor industries in Taiwan, of which the revenue of the wafer foundry industry and IC packaging and testing industry are positioned at number one globally. IC design industry is ranked in the second place, behind the United States. The Taiwanese semiconductor industry has employed a unique vertical disintegration method of the upstream, midstream, and downstream sectors to develop a complete industrial value chain that includes the following company types: upstream silicon materials and silicon wafer; midstream IC design, IC manufacturing, and IC packaging industries; and downstream computer, cellular phone, and consumable electrical product companies. The strength of the Taiwanese semiconductor industry has been advantageous to the developments of its solar photovoltaic industry.

3.2. Advantage of Industrial Clusters in Taiwan. The competitiveness of the industrial clusters in Taiwan has been appraised worldwide, ranking number one worldwide in 2007, 2011, and 2012 (see Table 2) [7-9]. Taiwan has occupied a lead position in the advanced industries such as semiconductor, PCs, and IT equipment. Over the past couple of years, the Taiwanese solar photovoltaic and semiconductor 


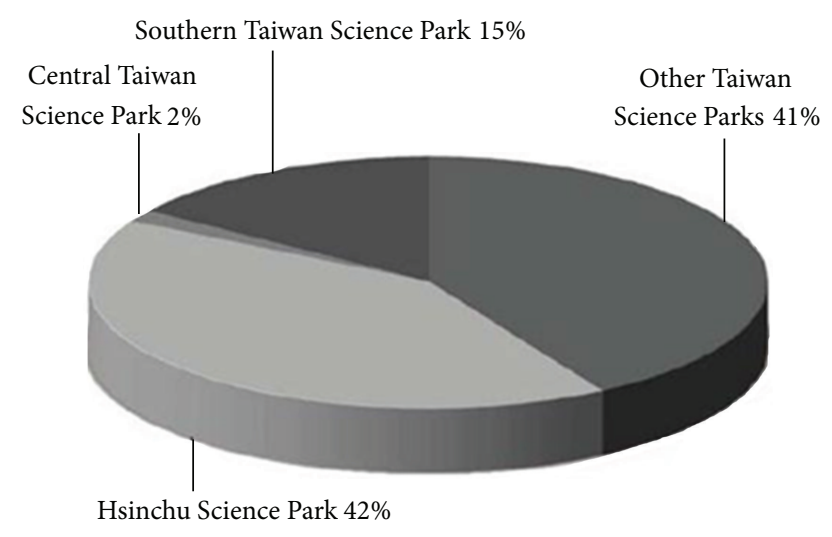

FIgURE 7: Revenue percentage of the Taiwanese solar photovoltaic industry (by Taiwan science parks). Source: PIDA (2012) [1].

industries have flourished with a series of companies entering first-generation solar cell production [18]. The advantages of industrial clusters in Taiwan have facilitated the rapid developments of the solar photovoltaic industry and the prompt establishment of a complete industrial value chain.

3.3. Clusters of Solar Photovoltaic Industry in Taiwan. Most of the Taiwanese solar photovoltaic companies are located at the Hsinchu Science Park, followed by the Southern Taiwan Science Park and the Central Taiwan Science Park. The industry revenue of the Hsinchu and Southern Taiwan Science Parks accounts for over $60 \%$ of the total (see Figures 7 and 8) [1].

(1) Hsinchu Science Park. Hsinchu Science Park was the earliest development of the solar photovoltaic industry in Taiwan. Based on the advantage of local electronic industries, there are many upstream silicon wafer factories in this science park. The overall annual income of the Taiwanese large five solar photovoltaic firms Motech, DelSolar, E-Ton, Gintech, and Neo Solar Power Corporation was approximately US $\$ 1.3$ billion in 2009, over $40 \%$ of the revenue in the Taiwanese solar photovoltaic industry [1].

(2) Southern Taiwan Science Park. The Southern Taiwan Science Park has the complete value chain of the solar photovoltaic industry with upstream, midstream, and downstream sectors. The revenue of the Southern Taiwan Science Park is approximately US\$530 million, 18\% of the revenue in the Taiwanese solar photovoltaic industry [1]. The large Taiwanese solar photovoltaic firms such as Motech, Kenmos Technology, Elite Material, MJC, and Nano-Win have production bases in the Sothern Science Park. This science park emphasizes the manufacturing of the components, the production of the chemical materials, and the developments of the solar photovoltaic and green energy industries.

(3) Central Taiwan Science Park. This science park has been successively invested in by 15 companies of thin-film photovoltaic cells, with the accumulated investment amount exceeding US\$4.33 billion [1]. This park also houses the primary production center of thin-film photovoltaic cells in Taiwan, which has received investments from at least 13 companies [1].

\section{Analysis of the Taiwanese Solar Photovoltaic Industry}

In the Taiwanese solar photovoltaic industry, approximately $80 \%$ to $90 \%$ production capacities are occupied by the solar cell firms. In this section, I focused more on the solar cell sector. At the moment, $98 \%$ of the photovoltaic battery industry is dependent on export [21]. The Taiwanese solar cell suppliers export most of their product, ranking as China (24\%), Germany (13.9\%), Spain (9.4), United States (8\%), and South Korea (7.9\%) (see Figure 9) [15].

The large size and R\&D capabilities of the Taiwanese semiconductor and display industries provide an advantage to involve silicon wafer and thin-film photovoltaic cells sectors. The Taiwanese electronic industries provide full support for the production capabilities of the components of the module-ends and system-ends in this industry. The Taiwanese companies are successively investing in upstream materials to satisfy the demand for low-cost materials. For example, Formosa Plastic Group has invested in ethylene vinyl acetate (EVA), and LCY Technology Corporation has invested in polysilicon and silicon materials. The competitive advantages of the Taiwanese electronics industry have provided a foundation for the developments of the Taiwanese solar photovoltaic industry.

4.1. History of the Taiwanese Solar Photovoltaic Industry. The solar photovoltaic industry has been developed in Taiwan for 25 years (see Table 3 ). The Taiwanese government promised to invest US\$666.67 million over five years to develop renewable energy technology, of all spending on energyrelated research, the amount spent on renewable energy accounted for $98 \%$, and of this solar energy R\&D accounted for $52 \%$ [21]. The Taiwanese firms began investing in solar cell $\mathrm{R} \& \mathrm{D}$ in 1987 . The initial $\mathrm{R} \& \mathrm{D}$ produced amorphous silicon cells. In 2004, the global renewable energy market emerged. Subsequently, the Taiwanese companies grew and the industry scale expanded [21]. Before 2007, the Taiwanese companies primarily invested in silicon wafers, silicon cells, and solar photovoltaic modules. When the price of polysilicon increased in 2008, the Taiwanese companies began investing large amounts of money into manufacturing of silicon thin-film photovoltaic cells [5, 22]. In 2009, the Taiwanese solar cell industry achieved $12.2 \%$ global production capacity, ranking top fourth in the world $[1,21]$. Furthermore, the Taiwanese government has set the solar photovoltaic industry as the emerging industry for prioritized support and promoted the "Green Energy Development Plan" to increase the development of the green energy industry. In 2009, this plan was approved as the "Renewable Energy Development Bill". In 2010, renewable energy feed-in tariff rates were established, since market price and investment incentive are the dominant factors that affect market acceptance of solar energy installation in Taiwan [5, 23]. 
TABLE 2: Rank of industrial clusters.

\begin{tabular}{lccc}
\hline & $2009-2010$ & $2010-2011$ & $2011-2012$ \\
\hline 1 & Japan & Taiwan \\
2 & United States & Japan & Italy \\
3 & Italy & Taiwan & Japan \\
4 & Hong Kong & Finland \\
5 & Singapore & Singapore & Singapore \\
6 & Taiwan & United States & Hong Kong \\
7 & Finland & Hong Kong & Sweden \\
8 & Canada & Sweden & Switzerland \\
9 & Switzerland & Finland & United States \\
10 & Sweden & United Kingdom & Qatar \\
\hline
\end{tabular}

Source: WEF Global Competitiveness Report (2010, 2011, 2012) [7-9].

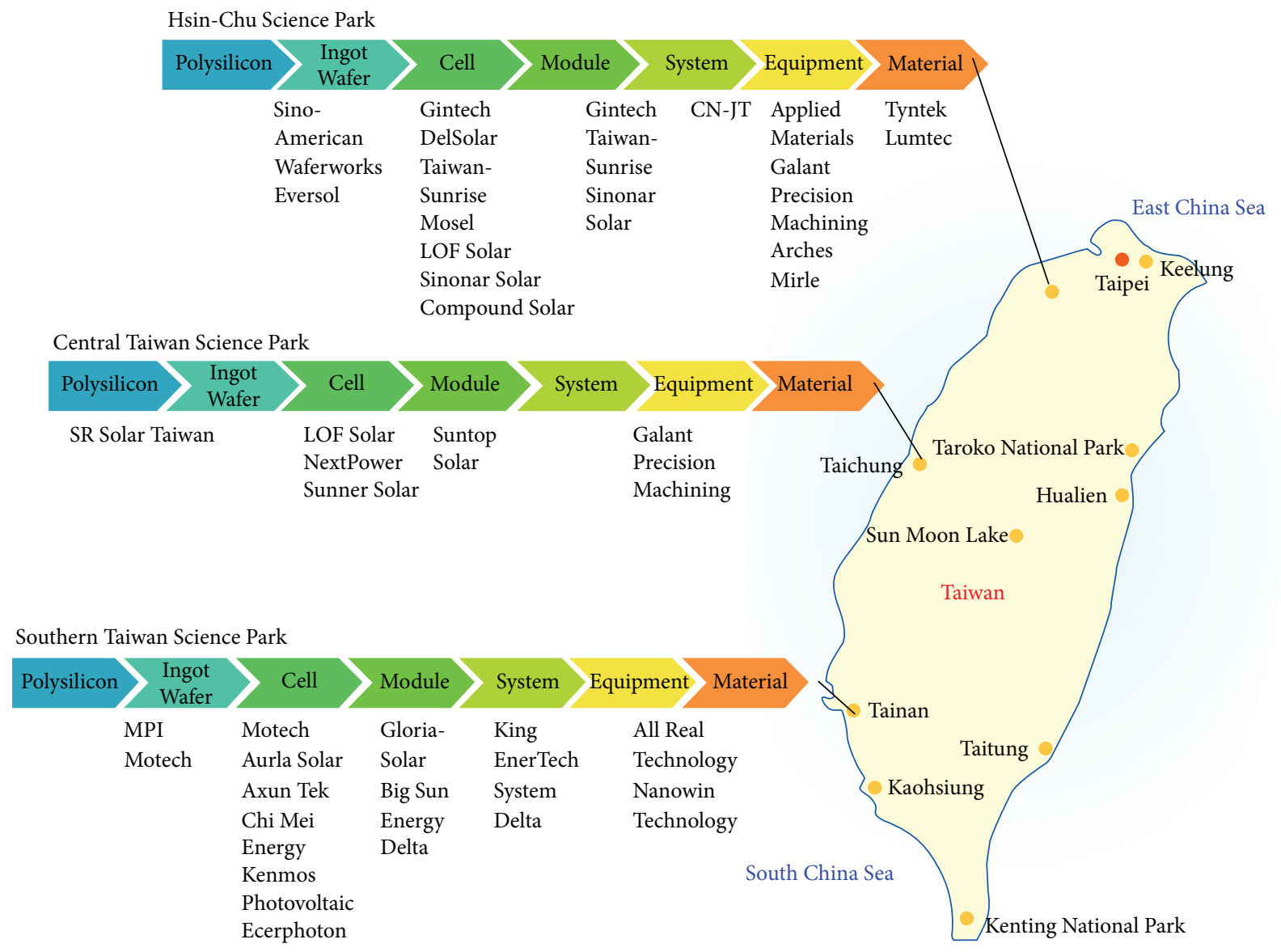

FIgURE 8: Solar photovoltaic firms in Taiwan Science Parks. Source: this study.

4.2. Value Chain Analysis of Taiwanese Solar Photovoltaic Industry. The most rapid growth in annual cell and module production over the last five years could be observed in Asia, where China and Taiwan together now account for over $60 \%$ of worldwide production [24]. In 2011, the percentage of global solar cells produced in Taiwan (15\%) and China (61\%) and the production of Taiwan and China exceeded $76 \%$ globally $[1,6]$. And overall Asia reached $82 \%$ global capacity [1]. Regarding the Taiwanese solar photovoltaic industry, not only the industrial value chains and industrial clusters have been established but also have the Taiwanese companies accorded with international standards. Therefore, the revenue of the solar photovoltaic industry is increasing annually. The overall revenue for the top ten Taiwanese solar cell companies was approximately US\$5.6 billion in 2011 and achieved a positive growth rate of $87 \%$ in the last five years (see Table 4 ) [10].

The solar photovoltaic companies are categorized according to their location in the industrial value chain: (1) upstream: silicon materials and silicon wafer; (2) midstream: 
TABLE 3: The history of Taiwanese solar photovoltaic industry

\begin{tabular}{|c|c|}
\hline Time & Item \\
\hline 1987 & Taiwanese firms began investing in solar cell R\&D \\
\hline 2004 & $\begin{array}{l}\text { Taiwanese companies invested and the industry } \\
\text { scale grew }\end{array}$ \\
\hline Before 2007 & $\begin{array}{l}\text { Silica wafers, silicon cell, and modules were } \\
\text { primarily invested }\end{array}$ \\
\hline 2008 & $\begin{array}{l}\text { Silicon wafer and thin-film photovoltaic cells were } \\
\text { largely invested }\end{array}$ \\
\hline 2009 & $\begin{array}{l}\text { Taiwanese government promoted the "green energy } \\
\text { development plan" and "renewable energy } \\
\text { development bill" }\end{array}$ \\
\hline 2009 & $\begin{array}{l}\text { Taiwanese solar cell production ranked top } 4 \text { in the } \\
\text { globe in } 2009\end{array}$ \\
\hline 2010 & $\begin{array}{l}\text { Renewable energy feed-in tariff rates were } \\
\text { established }\end{array}$ \\
\hline 2010 & $\begin{array}{l}\text { Taiwanese solar cell production ranked top } 2 \text { in the } \\
\text { globe in } 2010\end{array}$ \\
\hline 2011 & $\begin{array}{l}\text { Taiwanese solar cell production ranked top } 2 \text { in the } \\
\text { globe in } 2011\end{array}$ \\
\hline
\end{tabular}

Source: this study.

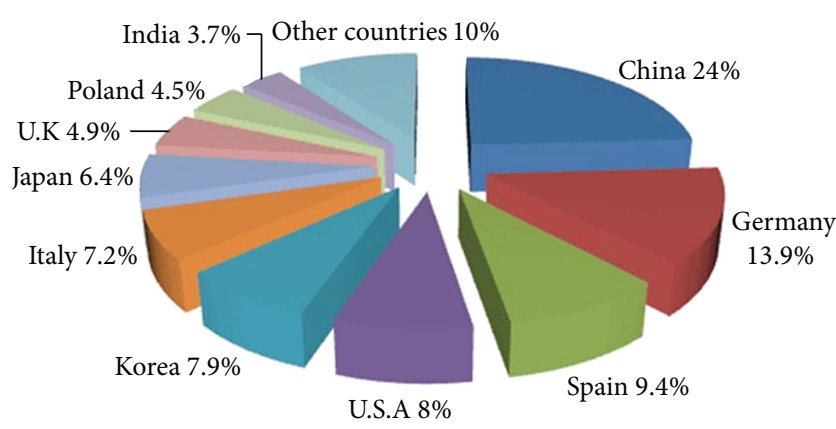

FIGURE 9: Proportion of Taiwan solar photovoltaic export. Source: Directorate General of Customs (2010) [15].

solar cells and solar photovoltaic modules; and (3) downstream: solar photovoltaic systems. Currently, there are 21 upstream companies, 61 midstream companies, and 49 downstream companies in Taiwan (see Figures 1 and 10) $[1,16]$. Additionally, several companies have adopted the vertical integration to integrate upstream, midstream, and downstream sectors in an effort to expand into large and international companies. Large solar cell companies can use their cost advantages to offer lower-priced products and consequently customers will buy more solar systems [24].

(1) Upstream Sector. The Silicon-Based Solar industry has growth quickly which has three reasons [25]. The first reason is that Silicon-Based Solar industry had subsidy from the government. The second reason is that when the gasoline price is rising, the Silicon-Based Solar industry has substitution effect to make highly production value. The third reason is that the Taiwanese top companies and international silicon material companies have signed a long-term contract and expanded the upstream industry.

(a) Silicon Materials. Because of technical barriers and sourcing difficulties, companies typically ally with international companies to establish factories or engage in technical cooperation to arrange an upstream supply chain. For example, Formosa Plastic Group and Chinese Petroleum Corporation both partnered with international companies to build factories and expand their production capacities, subsequently increasing the supply of the raw materials for the companies in the midstream and downstream sectors [5].

(b) Silicon Wafer. The successful semiconductor industry in Taiwan has lowered the entry barriers for the Taiwanese companies entering in the solar photovoltaic industry, generating a continuous increase in the capacity of the silicon wafer production.

(2) Midstream Sector. Midstream and downstream industries have lower entry barriers and have become the main aspects of the solar photovoltaic industry in Taiwan. The production capacity of the midstream solar cell and module sector in Taiwan has been ranked top two in the world. In 2010, the value of Taiwanese solar cell exports was US $\$ 4.3$ billion. A growth rate of $61.5 \%$ has been achieved in the last five years [26]. Typically, companies invest in upstream silicon materials to stabilize the supply of these materials. Thus, the companies with the highest production capacity (such as Motech, E-Ton, DelSolar, and Gintech) have signed a long-term cooperation contract with international silicon materials companies.

Additionally, the Taiwanese companies have tended to pursue the latest thin-film cell technologies. Stion Company in the United States has authorized and transferred CIGS thin-film production rights to Taiwan Semiconductor Manufacturing Company (TSMC), and TSMC has provided solar cell modules to Stion Company. Both companies have simultaneously developed thin-film photovoltaic technologies. Similarly, AU Optronics Company in Taiwan and SunPower Technology Corporation in the United States have invested in a solar cell company in Malaysia to establish a complete value chain in solar photovoltaic industry.

(3) Downstream Sector. The Taiwanese government has promoted and subsidized the policies of the renewable energy industry, and thereby increased the revenue of the downstream companies. Downstream companies achieve profits by product assembly and maintenance [13]. The Taiwanese companies, such as TSMC and Motech Industries Incorporation, have adopted the vertical integration to stabilize product supply, establish sales channels, and create their own brands.

With the increase in global production and market competitiveness, the Taiwanese companies are committed to reducing costs and achieving vertical integration to develop distinguishable features and become a leader of the field. To avoid profit declines caused by competitive pricing, several companies have invested in downstream distributors and branding. In the future, companies that adopt vertical 
TABLE 4: Top 10 Taiwanese solar photovoltaic suppliers.

\begin{tabular}{lcccc}
\hline & 2007 & 2008 & 2009 & Gintech \\
\hline 1 & Motech & Motech & Gintech & Motech \\
2 & Gintech & Gintech & Motech & Neo Solar Power \\
3 & E-Ton Solar Tech & E-Ton Solar Tech & E-Ton Solar Tech & E-Ton Solar Tech \\
4 & DelSolar & Neo Solar Power & Neo Solar Power & Solartech Energy \\
5 & Neo Solar Power & DelSolar & DelSolar & DelSolar \\
6 & Solartech Energy & Solartech Energy & Solartech Energy & Tainergy Tech \\
7 & TYNSOLAR & TYNSOLAR & GLORIA SOLAR & Big Sun Energy Technology \\
8 & MOSEL Ectronics Taiwan & MOSEL Ectronics Taiwan & Apollo Solar Energy & Next Power Technology \\
9 & Big Sun Energy Technology & GIH & BIG SUN Energy Technology & Apollo Solar Energy \\
10 & Apollo Solar Energy & Apollo Solar Energy & Inventec Solar Energy &
\end{tabular}

Source: China Credit Information Service (2011) [10].

integration and control material resources and technologies will have the most competitive advantages.

4.3. Trends of Solar Photovoltaic Technology. Currently, solar photovoltaic modules are used globally as a-silicon cells and poly-silicon cells [22]. Besides a-silicon cells and polysilicon cells, Taiwanese companies have begun developing inexpensive next-generation thin-film photovoltaic cells. This market is currently dominated by crystalline silicon-based PV cells, which accounted for more than $80 \%$ of the market in 2010 , and the remainder $20 \%$ of the market almost entirely consists of thin film technologies that use cells made by directly depositing a photovoltaic layer on a supporting substrate [20]. However, investments are not yet significant in this field because of difficulties in material acquirement and immature technologies.

The primary characteristics of the solar photovoltaic technologies are efficiency, productivity, and pricing. The Taiwanese firms should accelerate the independence and differentiation of the solar photovoltaic technologies, obtain patents for new types of the solar cells and new technologies of solar photovoltaic modules, and invest in nextgeneration technologies (such as compound solar cells and dye-sensitized solar cells). The solar photovoltaic market will lead future technological developments. And the main technological developments will include higher conversion efficiency rates, lower costs, and access to sufficient material sources. The Taiwanese companies like to ally with international companies with advanced conversion rate technologies to enhance their product competitiveness in the global market.

4.4. SWOT Analysis of the Taiwanese Solar Photovoltaic Industry. The SWOT analysis of the Taiwanese solar photovoltaic industry is made in this study.

(1) Strength. Industrial clusters have been established comprehensively by electronics, information technology, and precision machinery industries in Taiwan. With its industrial clusters ranked top one in the world, the Taiwanese solar photovoltaic industry has more competitive advantages compared to those of other countries. The Taiwanese solar photovoltaic industry, which employs upstream, midstream, and downstream sectors, has received investment from many companies, completing the industrial value chains. The production capacity of the Taiwanese solar cells is ranked top two globally. And many advantageous products are produced, such as silicon wafer and silicon solar cells. There are numerous talents specialized in the field of IC, LED, and electronics technologies in Taiwan, consequently reducing the time of R\&D and production, and increasing the efficiency of R\&D. Furthermore, the Taiwanese firms have invested in the R\&D of the next-generation products of the thin-film photovoltaic cells.

(2) Weakness. The size of domestic market in Taiwan for solar products is small. Approximately $97 \%$ of products are created for export. The amount of exports depends on the solar photovoltaic usage by other countries. Additionally, $98 \%$ of the raw materials are imported. Therefore, production is also restricted by upstream raw materials companies. Large international companies in the United States, Japan, and Germany are vertical integration, which provides a complete service system. By contrast, few Taiwanese companies possess capabilities of vertical integration.

(3) Opportunity. The global solar photovoltaic market is growing vigorously, with the majority of global production concentrated in Asian countries. Taiwan is not only an essential base of production but also provides opportunities to enter the market rapidly. Applications of solar cell products are broad and demanding and widely used by public and private companies. With the advantages of the electronic industries, the Taiwanese firms can develop differentiated and distinct solar products. Also, the global shortage of fossil fuels is one of the factors that led to many countries focusing on the renewable solar photovoltaic industry. PV prices experienced a remarkably steady decrease, realizing more $80 \%$ cost reduction on a $\$ /$ Watt peak basis from 1973 to 2011 [27]. And, the decline in prices of solar modules has drive solar photovoltaic industry growing rapidly [27]. 


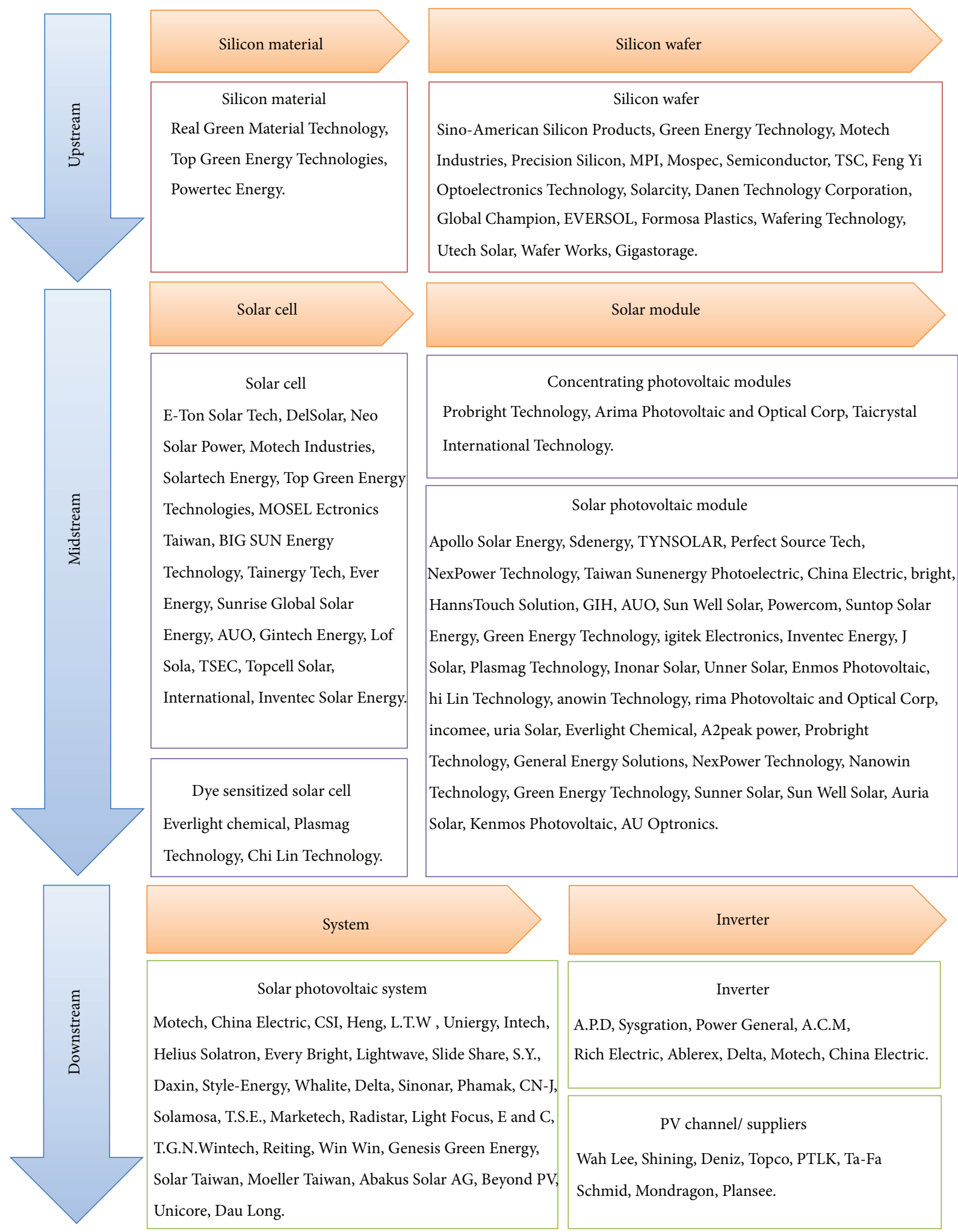

FIGURE 10: Value chain of the Taiwanese solar photovoltaic industry. Source: Green Energy Industry Information Net (2012) [16]. 
(4) Threat. The reduction of subsidies for solar photovoltaic products in many countries has caused a temporary decrease in demands and a decline in the growth of the solar photovoltaic market. The R\&D capabilities of solar photovoltaic technologies are pioneered by the United States, Japan, and Germany; thus, these countries have advantages in both technologies and the markets. Moreover, the Chinese photovoltaic industry is developing rapidly; the capacity of the Chinese solar photovoltaic production is ranked number one globally, facilitating continuous expansion. In South Korea, strong electrical industries accelerated the developments of its solar photovoltaic industry, becoming the primary competitor of Taiwanese firms.

\section{Conclusion}

Based on its strong electronic industries and complete industrial value chain, the Taiwanese companies are making large investments into its solar photovoltaic industry. The production capacity of the Taiwanese solar photovoltaic industry is ranked top four globally. The Taiwanese companies have more competitive advantages in the midstream sector of solar cells in the global value chain, ranking top two in the world. Different from the USA, German, and Japanese companies that have technological and industrial advantages in upstream sector and focus more on R\&D capabilities, Taiwanese smaller companies have to specialize in niche markets with high value added in their products in order to compensate the advantage of large companies made possible by economies of scale that come with large production volumes. Moreover, the other possibility of the Taiwanese firms is to offer technologically more advanced and cheaper solar cells, though Chinese and South Korean companies emerged fast by low-price competition recently. The Taiwanese solar cells are preferred by the international companies because of its substantial technologies, low costs, high conversion efficiencies, stable product quality, and reasonable pricing. Based on the competitive advantages, the Taiwanese firms can continue to expand to the future emerging markets. The Taiwanese companies will continue to have an important and indispensable role in the global solar photovoltaic industry.

\section{Conflict of Interests}

The author does not have a direct financial relation with the commercial identity mentioned in the paper that might lead to a conflict of interests.

\section{References}

[1] Photonics Industry \& Technology Development Association, Analysis of Solar Industry in the Globe, Photonics Industry \& Technology Development Association, Taipei, Taiwan, 2012.

[2] F. Diner, "The analysis on photovoltaic electricity generation status, potential and policies of the leading countries in solar energy," Renewable and Sustainable Energy Reviews, vol. 15, no. 1, pp. 713-720, 2011.
[3] F. Chen, S. M. Lu, K. T. Tseng, S. C. Lee, and E. Wang, "Assessment of renewable energy reserves in Taiwan," Renewable and Sustainable Energy Reviews, vol. 14, no. 9, pp. 2511-2528, 2010.

[4] Energy Trend, Solar Industry Report, Energy Trend, 2012.

[5] C. T. Tso, Launch a New Engine in Taiwan: The Niche and Challenge of the Energy Industry in Taiwan, Taiwan Institute of Economic Research, Taipei, Taiwan, 2011.

[6] Solarbuzz, PV Equipment Quarterly, Solarbuzz Solar Market Research and Analysis, 2012.

[7] K. Schwab, The Global Competitiveness Report 2009-2010, World Economic Forum, Switzerland, 2009.

[8] K. Schwab, The Global Competitiveness Report 2010-2011, World Economic Forum, Switzerland, 2010.

[9] K. Schwab, The Global Competitiveness Report 2011-2012, World Economic Forum, Switzerland, 2011.

[10] J. R. Wu, The Report of the Ranking of the Large Enterprises in Taiwan, China Credit Information Service, Taipei, Taiwan, 2011.

[11] Photon International, The Solar Power Magazine, Photon International, 2012.

[12] Industrial Technology Research Institute, Global Solar Photovoltaic Market Analysis, Industrial Technology Research Institute, Hsinchu, Taiwan, 2012.

[13] J. Z. Shyu, J. S. Wang, and C. C. Peng, The Developmental Strategy of the Emerging Energy Industry, Hwatai Publishing Company, Taipei, Taiwan, 2010.

[14] C. Y. Wu and J. A. Mathews, "Knowledge flows in the solar photovoltaic industry: insights from patenting by Taiwan, Korea, and China," Research Policy, vol. 41, no. 3, pp. 524-540, 2012.

[15] Ministry of Finance, Directorate General of Customs, Ministry of Finance, Taipei, Taiwan, 2011.

[16] Green Energy Industry Information Net, 2012.

[17] Semiconductor Equipment and Materials International and Materials International, Global Solar Market in 2011, Semiconductor Equipment and Materials International, 2011.

[18] J. A. Mathews, M. C. Hu, and C. Y. Wu, "Fast-follower industrial dynamics: the case of Taiwan's emergent solar photovoltaic industry," Industry and Innovation, vol. 18, no. 2, pp. 177-202, 2011.

[19] Y. C. Lin, The Market Trends of the Photovoltaic Industry, Industrial Technology Research Institute, Hsinchu, Taiwan, 2010.

[20] R. T. Govinda, L. Kurdgelashvili, and P. A. Narbel, "Solar energy: markets, economics and policies," Renewable and Sustainable Energy Review, vol. 16, no. 1, pp. 449-465, 2012.

[21] H. M. Liou, "Policies and legislation driving Taiwan's development of renewable energy," Renewable and Sustainable Energy Reviews, vol. 14, no. 7, pp. 1763-1781, 2010.

[22] T. M. Razykov, C. S. Ferekides, D. Morel, E. Stefanakos, H. S. Ullal, and H. M. Upadhyaya, "Solar photovoltaic electricity: current status and future prospects," Solar Energy, vol. 85, no. 8, pp. 1580-1608, 2011.

[23] C. D. Yue and G. R. Huang, "An evaluation of domestic solar energy potential in Taiwan incorporating land use analysis," Energy Policy, vol. 39, no. 12, pp. 7988-8002, 2011.

[24] A. Jäger-Waldau, "Thin film photovoltaics: markets and industry," International Journal of Photoenergy, vol. 2012, Article ID 768368, 6 pages, 2012.

[25] C. C. Chen, T. Y. Hsieh, and Z. S. Lin, "An analysis of siliconbased solar industry operation performance in Taiwan," Social and Behavioral Sciences, vol. 57, pp. 306-311, 2012. 
[26] J. R. Wu, Optoelectronic Materials and Components Manufacturing Industry-Solar Cells-Price Or Industry Loss, China Credit Information Service, Taipei, Taiwan, 2011.

[27] B. Algieri, A. Aquino, and M. Succurro, "Going "green": trade specialization dynamics in the solar photovoltaic sector," Energy Policy, vol. 39, no. 11, pp. 7275-7283, 2011. 

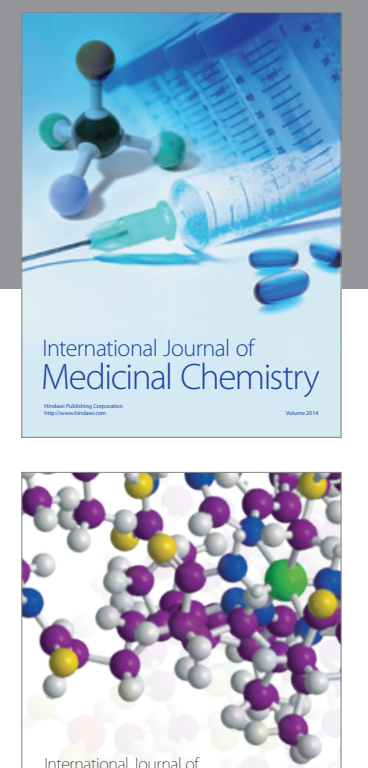

\section{Carbohydrate} Chemistry

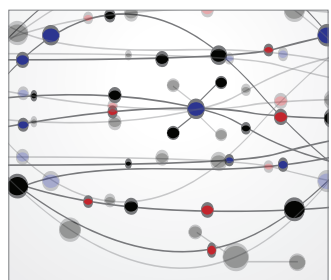

The Scientific World Journal
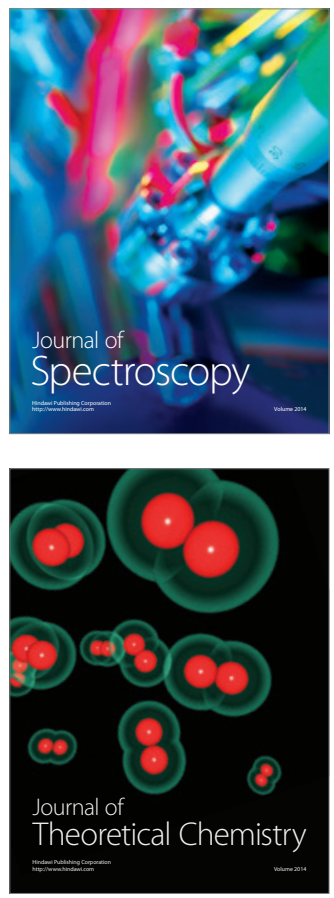
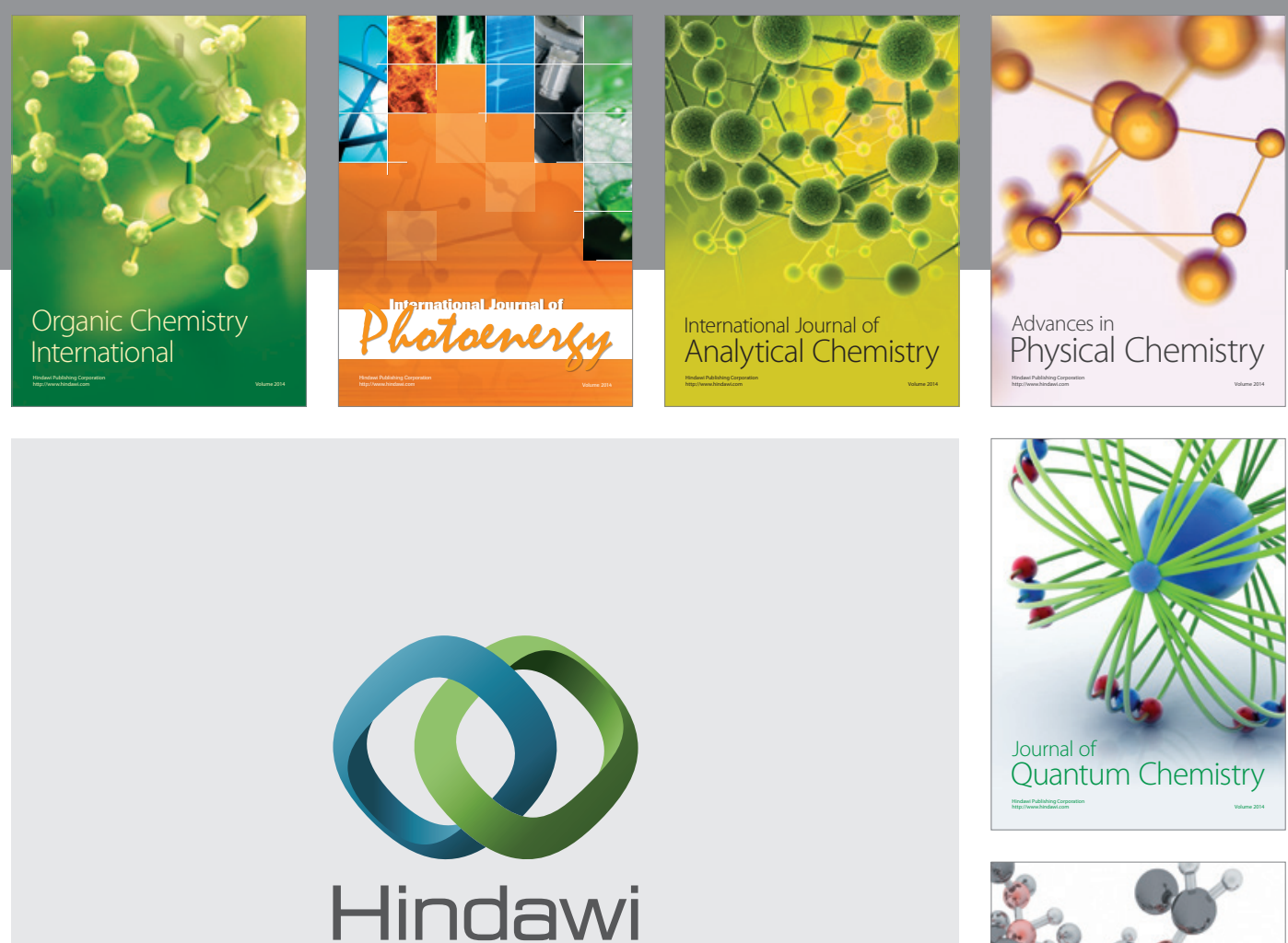

Submit your manuscripts at

http://www.hindawi.com

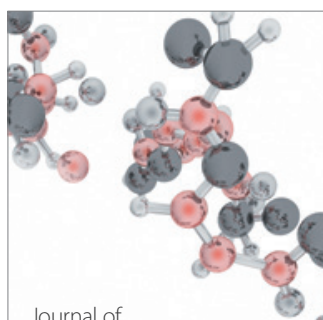

Analytical Methods

in Chemistry

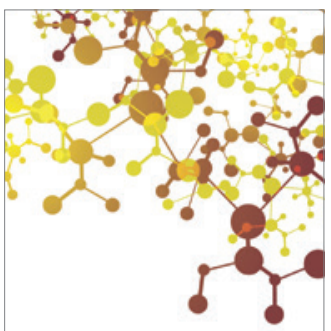

Journal of

Applied Chemistry

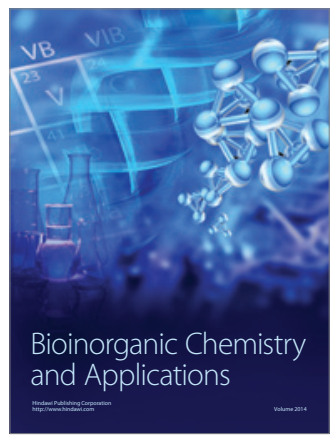

Inorganic Chemistry
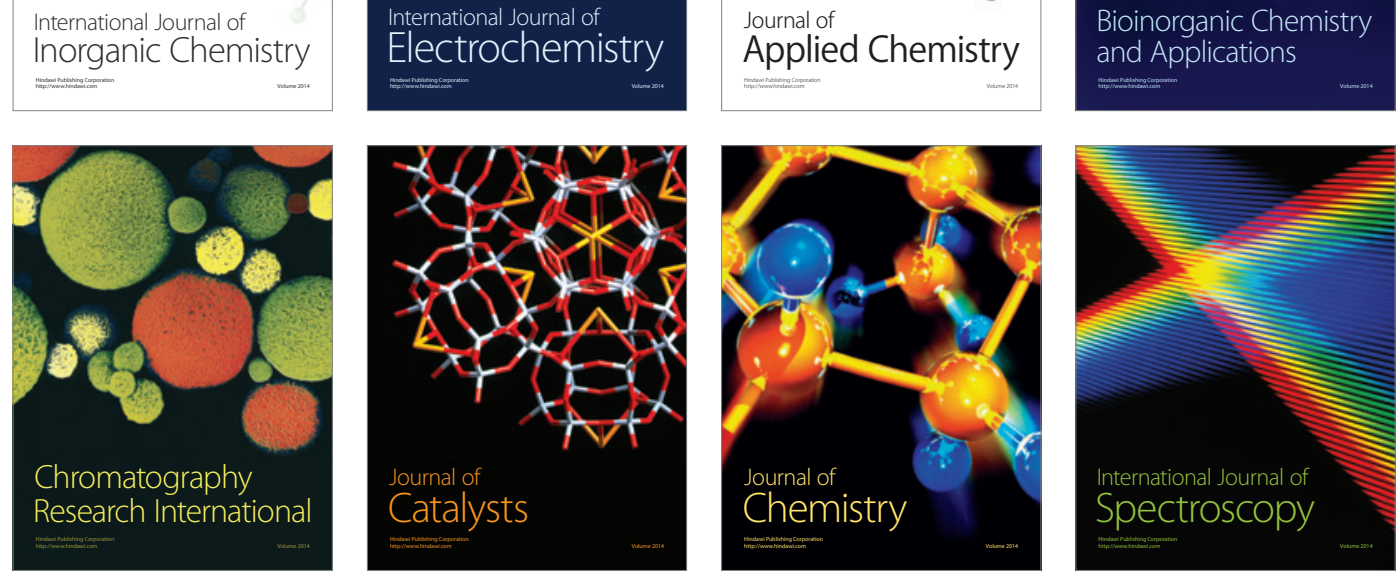